International Journal of English Literature and Social Sciences
Vol-6, Issue-2; Mar-Apr, 2021
Journal Home Page Available: https://ijels.com/
Journal DOI: $10.22161 /$ ijels

\title{
The Seats Stay Unmoved: Theatre, Audience and Engagement
}

\author{
Megha Mazumdar
}

MA, Department of English Literature, St. Xavier's College, Kolkata.

Received: 22 Dec 2020; Received in revised form: 19 Feb 2021; Accepted: 18 Mar 2021; Available online: 11 Apr 2021

(C)2021 The Author(s). Published by Infogain Publication. This is an open access article under the CC BY license

(https://creativecommons.org/licenses/by/4.0/).

\begin{abstract}
Dramatization of reality has been a fodder to the human mind since time immemorial. The discovery of dramaturgy and serious theatricality just aggravated the mechanism further. Since the entire phenomenon is highly relevant in the eyes that watch, adopting important measures to keep the watch going, is necessary. The concern of audience engagement can be studied, based on the architecture of the theatre, the ambience of it, and with modern evolutions going on, new modes of attraction like food and refreshment turn out to be of great importance. The essay mentions a critical approach in analysing the psychological tendencies of the audience, with the continuous flux in time and hence the mechanisms, as put forward by several playwrights over the ages and locations. The inference is a step taken to align and conclude how the basic psychological aspects of audience engagement remain the same, since the time of the proscenium to the modern terms of theatricality, even in the times where the space of performance is contracting gradually to end up being confined in a box.
\end{abstract}

Keywords - dramaturgy, watch, psychological tendencies of the audience, flux, performance

\section{INTRODUCTION}

"Don't expect the theatre to satisfy the habits of the audience, but to change them".

(Bertolt Brecht, 1957)

The construction of the idea of the significance of audience engagement in a theatre, has been an area of uncertainty since time immemorial. The minimum facets of entertainment through portrayal of the realistic justification of the societal tantrums is a prosperous service of the theatre. Be it from the times of the Proscenium or those of the Third Theatre, the audience becomes the soul of each performance- the spectator needs to judge the performer who then justifies his actions through the eyes of his 'only' beholder. Equalising the impact of every kind of theatrical make-up, one important modus operandi that ultimately becomes prominent through further observation is the 'type' and 'age' of the audience. The dramatic endeavour that is being portrayed on the stage needs to connect with the one watching it. There ought to be a continuous conversation going on between the mind of the actor and that of the spectator, that will eventually formulate a relationship between the two, where the one watching the action will retain the maximum amount of impact of the very action, even after the play is over.

\section{THE RESPONSE}

As Brecht goes on, "a theatre which makes no contact with the audience, is nonsense" (1946), we are bound to see the shifts in the paradigm of the theatrical development over the eras, where audience engagement, from an instinct, becomes a 'must'. During the important times of the Greek theatre, when Aristotle himself dared to raise his postulates on what a play and thus, its performance should contain, the crowd saw it as an entailment of themselves to be a part of these theatrical creations where they would consider a competition, in a carnival, among the different plays performed and would fairly vote for the 'best' one, which seems visibly distinct from the postulates of the seventeenth century theatre, where 'indoor theatre' became the flavour of the time. 
As Susan Bennet writeshow the audience became "increasingly passive and increasingly bourgeois" (1997), which again makes our focus shift on the advent of the class consciousness in the society, differing from the otherwise Dionysius mentality that had prevailed. Furthering our observation down the axis of the Modern European Theatre, we see the extreme measures taken against the selectivity of the class of audience by erudite like Henrik Ibsen, Samuel Beckett, Bertolt Brecht and even the Italian enigma, Luigi Pirandello, by tearing down the passive and bourgeois element of the audience. But that enhances the dilemma in the extent of engagement of the audience: Are they invested in the story? Do they respond enthusiastically when appropriate? Are they discussing the themes of the play afterwards? These playwrights/ directors tried to synchronise or at least tie a chord between the events on the stage and that among the audience, which later came to be known as the Metatheatre, the mood that was created among the characters on the stage was observed to be occurring among the spectators- thus keeping them engaged through the persuasion of their emotion, as seen in Waiting for Godot by Beckett where Vladimir and Estragon's wait becomes a wait among the audience too for the appearance of Godot. Pirandello on the other hand, took the Metatheatrical aspects on a different level when he dissolved the boundaries between the actors and the characters in his Six Characters in Search of an Author, where the actors themselves became the audience and the characters were given the poststructuralist justification as declared by Barthes and Derrida.

\section{INTERPRETATIONS AND MEASURES}

A very significant way of dealing with audience engagement issue is making sure that the audience is aware of the content of the play and has the minimum number of intimations required to see beyond what is shown. A background study of the subject is extremely important for the audience to realise the actual virtue of the act, to let the ideas proliferate in their heart and mind and so that they can measure the highs and rationalise the lows. Another way of making the masses realise the true value of the play is Theatre Education. Adult theatre education is analogous to moving away from the superficiality of the presentations and arguments to experience-based enactments. This way, the cognitive studying ability merges with the expressively creative ones and talks and quarrels are replaced with formal discussions and workshops, and practicallycreative acts. There is an emerging range of specialists who aid in purposing these activities, whether they are called educationalists, animators, or facilitators; they often have an artistic background themselves. As Alan Brown and Rebecca Ratzkin say "benefitting from arts experiences often requires a great deal of contextualization and interpretation"

Researcher Jeanne Klein puts it in a more statistical way. She classifies the quality of the audience members into two categories; The "Ritualistic" viewerwho seeks entertainment by watching theatre "passively out of habit, although their minds are still quite actively processing information," and the "Instrumental" viewerwho "actively seek[s] further education by expecting to learn social information of specific interest to their personal identity, in relation to characters' dramatized situations". In both the situations, the construction of the play should be thus that it has both thought laden impediments as well as the perfect measurement of the entertainment. Audience engagement also helps in re-visiting the social texture of the contemporary and re-enhance the folds and voids. It is also a great step taken for socialisation that, in turn, changes and transforms human relationships. It requires a community building- a performance that is merged with scholarship which turns the personal into political. Language helps in this role play since it is extremely transformative itself but embodied at the same time. To compensate for, rather improvise overpower, "over" with power "with", audience engagement becomes an extremely fruitful phenomenon. This uses the audience engagement to demystify the thrutch between the time and space realms of the on and off-stage engagements respectively.

Theatre is ancient and extremely sacred in its artistic expenses. It has empowered and galvanised the human existence since pre-historic times. However, in modern society with the interruption of the industrial cinematic and now digital age, the spectators often go to the theatre to relax. While the other forms of literary weapons like novel and poetry, help the readers to connect on a personal level, theatre serves the purpose of relaxation on a different level- it engages the audience to judge the actions, coming out of their personal normativity, and analyse. Instead of embracing and embodying the action of the play as something personally relatable and necessary to their own lives, they remain removed from it and judge it from a distance, from the eyes of the spectator and not as one of them. A genuinely efficient theatre company investigates these welfares of the audience in establishing intellectual and emotional connectivity. As mentioned, Shakespeare's theatres were run with the sole purpose of audience satisfaction. Theatrical creations can potentially heal, enrich, preach, comfort, provoke, activate, and open minds and hearts. 
With considerable development in all these aspects, when the audience is allowed to engage with these occurrences mentally, physically, intellectually and spiritually with constant improvised development, the power of theatre expands to include both, a deeper awareness of and empathy for humanity, and a real potential for positive change. Powerful essays of Brown and Ratzkin have concluded how audiences need to engage intimately with their own personal perceptions to compare those with the ones being portrayed on stage. More than just watching what is going on, one needs to simultaneously go on deriving meaning out of the same:

the level of impact that an audience member derives from an arts experience can be dramatically affected through his or her participation in meaning-making activities or self-guided reflection(Brown and Ratzkin, 2012)

\section{THE CRITICAL EMBASSY}

As A.G. Johnson mentions, "Of all human needs, few are as powerful as the need to be seen, included, and accepted by other people", another justification of the audience engagement can be virtually mentioned with the reason of being seen and noticed by the actors. As we see this with the modern urge of people to connect, be it for the continuous use of cell phones, or something else, which, in fact, makes the rationalisation of the third theatre in India where the actors dared to disintegrate the proscenium happened to engage more freely with its audience where interaction became easy and rejuvenating, sparing even a single moment of boredom and monotony. With the advent of mobile entertainment canters, people can have the solo experience of watching movies or television shows through ear buds and virtual headgear. Theatre is an enigmatic persuasion. The physical aspects of the theatre hall are also equally contributing. Once the light is turned out, the comfort of the seat with the rich measurement of temperature inside, the perfect bite of the delicious munchies- these are the necessities, which profusely engage with the interest of the audience too.

The very idea of individual audience engagement can also be morphed through Vygotsky's theory of Social Development, which of course is applicable to a child's mind, who learns around people primarily, and then go on to think independently with their own individualistic perceptions, and implement their thoughts based on what they have already learned. This is equally analysed by Susan Bennet, where she enforces this kind of an attitude among the audience too who, come to watch a performance, acquire some knowledge from the way the play is portrayed, and then go out to visualise the same scenarios with the perceptions, gained in the theatre- the first interaction takes place among the people, and then within the individual's mind.

Now as the discussion proceeds with the impact of the performance on the spectator's mind, most of the premodern and modern playwrights from almost every corner of the literary universe, prescribe the articulation of the play by the audience by keeping it open-ended. The content ought to be wholesome but the ending needs to be abrupt- so that the audience stay interested and attached to it and spend enough time, building up the structure whose puzzle pieces were given by the actors on the stage, and they get to fit them according to their individual preferences and readings. The suggestion of breaking the performance with an interval in the middle in some parts of the world, seems ambiguous. It has a half to full preference by different spectators. Some of them believe in the break less continuity of the performance while the rest prefer a break in the middle, not a lengthy one, but quite enough to allow them with the time to think and contemplate over it, that in fact, brings about a stronger foundation of interests. Heathcote transfers this mechanism within the embrace of the personal psychological study of the people who do not prefer any kind of distractions against those who believe in utilising that very distraction to be better at what they are doing.

Considering the personal approaches of the actors themselves, there has been a thick line of distinction between the two types of actors- the ones who follow the Greek pattern of theatre interaction are more likely to involve the audience, where there is continuous intimacy between the actors and the people watching them act, and the boundary of involvement stretches beyond the boundary of space when the actors choose to continue with their portions, standing among their audience too. Whereas the other set of actors, preferably known as the naturalists prefer to imagine a "fourth wall" between them and the audience and do not care much about the engagement with the audience, which, in turn, becomes a difficult situation and has to be compensated with a greater performance and plot, maybe. In other instances, the actor may address the audience one moment and play as though there were a fourth wall the next. The Living Theatre, formed in 1947 in New York City by Julian Beck and Judith Malina, first proposed on engaging the audience in direct personal and physical contact. In the 1970s, Augusto Boal of Brazil developed the Theatre of the Oppressed, in which performance was intended to serve the triple function of entertainment, education, and consciousness-raising. Similar techniques found wide use in the 1970s and ' 80 s in such movements as feminist theatre, homosexual theatre, black theatre, prison theatre, 
theatre of the deaf, theatre of the handicapped, and theatre of the aged.

There is also a constant clash between the character and the actor. There are certain norms, which the actor is expected to abide by, which might not at all be a criterion in the character. This space is responsible for many of the voids created between the actors and the audience. This quandary got its prominence more after the early Romantic rendezvous, when the theatre just was not being used for entertainment purpose, but it crystallised the political and social outcries of the contemporary society, thus paving a way for more vehement yet realistic plotlines today, like women subjugation. Audience interaction becomes more of a discomfort but yet extremely necessary in these cases since the actors are obliged to art and that is the only safe way to broadcast reality, which is harsh and thus, deserve a change.

Coming back to Aristotelian unities of time, space and action, the first is seen when the boundaries between the real and reel time is to be diminished and the spectators are to be convinced too, of the same. In some productions, especially those inspired by the antinaturalistic theories of the Russian director VsevolodMeyerhold, the audience is constantly reminded that it is in a theatre, which shows their priority in enhancing the quality and not bother with that particular branch of audience who do not care to flatter the content. Same

happens with the space or the location which necessarily has to diminish the challenges faced during making the stage disappear and bring the props and accessories into action to make it as realistic as possible so that audience attention stays at its zenith. As the action has been spoken about, the only additional information that needs to be circulated is the fact that the same naturalistic actors would prefer deliberately keeping a mask between their actual portrayal and the portion that is portrayed.

\section{CONCLUSION}

Concluding all the prospects of audience engagement what personally strikes a mark is the very fact that the ways of engaging the audience has changed quite a bit over the past half a dozen of centuries. Although some are strictly followed even today, but the high possibility of the age-old norms being followed depends on the location and the age-group of the crowd watching the play. Although the pillar of the power of theatre or be it any live stage performance stands quite vulnerable today in the post-modern etiquettes of worshipping technology, the rules, rather the wits of audience engagement stay the same. While a clean and proper hall in the west portrays a better quality of the play, the voice and simplicity of the actors engaged in the third theatre performances in the east, especially India, is prioritised. Thus, audience engagement is purely personal and has a long hand of affinities, depending half on the stated propositions, decided by the playwrights or the directors and half on the quality of the audience and their share of entertainment. Where "all the world's a stage", the portion of engaging into that stage, be it as an actor or a spectator, remains vital and mutually congruent.

\section{ACKNOWLEDGEMENTS}

It is worth mentioning how completing this essay would not have been possible without the continuous guidance of some of the influential people in my life, starting with my mother and my college professors, and our respected HOD, Dr Prof. Suchandana Bhattacharya.

\section{REFERENCES}

[1] Bennett, Susan. Theatre Audiences: A Theory of Production and Reception.1997. London: Routledge.

[2] Boal, Augusto. Games for Actor and Non-Actors, 2nd ed. Adrian Jackson, trans. 2009 London: Routledge.

[3] Brecht, Bertolt. John Willett, ed. 1964 "Emphasis on Sport." Brecht on Theatre: The Development of an Aesthetic. New York: Hill and Wang.

[4] Brown, A., \&Ratzkin, R. Making Sense of Audience Engagement.2009. San Francisco, CA: WolfBrown.

[5] Wooster, Roger. Theatre in Education in Britain: Origins, Development, and Influence. 2016. London: Bloomsbury Methuen Drama. 